\title{
The cult of the entrepreneur within the EU framework: The advance of an entrepreneurship activation model*
}

\author{
Antonio Santos Ortega \\ UNIVERSITAT DE VALÈNCIA (UV) \\ juan.a.santos\&uv.es \\ David Muñoz-Rodríguez \\ UNIVERSITAT DE VALÈNCIA (UV) \\ francisco.d.munoz\&uv.es \\ ORCID: 0000-0001-5672-8533
}

Received: 07/02/2018

Accepted: 23/07/2018

\begin{abstract}
This paper approaches the concept of 'activation' by looking at the notion of what an entrepreneur is. At present, the entrepreneur is Neo-Liberalism's Poster Child and is enshrined in EU-2020 programmes. It should be noted that the diffusion of entrepreneurship is taking place against the background of two great changes in the social and employment fields. The first is the progressive corporatisation of wage labour, with a drive towards individualisation and taking responsibility - mainly in qualified jobs. The second is the blurring of boundaries in salaried work due to the proliferation of new kinds of self-employment. Salaried work, especially for highly-skilled staff, is being re-cast in an entrepreneurial mould. This redefinition is forging new practices and archetypes that will transform the world of work. This paper therefore makes a deeper analysis of labour activation processes in the EU-2020 strategy through the idea of the entrepreneur.
\end{abstract}

Keywords: entrepreneurship, human capital, job insecurity, neo-liberalism, uncertainty, labour changes.

Corresponding author: Antonio Santos. Universitat de València, Facultat de Ciències Socials. Av. dels Tarongers, 4b. 46021, València (Spain).

Suggested citation: Santos, A. and Muñoz, D. (2019). The cult of the entrepreneur within the EU framework: The advance of an entrepreneurship activation model. Debats. Journal on Culture, Power and Society, 4, 13-24. DOI: http://doi.org/10.28939/iam. debats-en.2019-2

\footnotetext{
* This paper stems from the project L'emprenedoria com a estratègia de lluita contra la desocupació juvenil: de la política institucional a la vivència i experiència dels subjectes [Entrepreneurship as a Strategy for Fighting Youth Unemployment: from institution policy to subjects' experience and lifestyle] (CSO2017-82839-P), funded by Ministeri d'Economia, Indústria i Competitivitat [Ministry for the Economy, Industry and Competitiveness].
} 


\section{INTRODUCTION}

Entrepreneurs in social and economic fields are now very much in the media limelight. The dissemination of their role is unprecedented and should be seen against the background of The Sub-Prime Crisis. Formerly confined to purely economic and business spheres, the cult of the entrepreneur has spilt over into social and employment policies. Entrepreneurs have been given 'the glamour treatment' and the cult permeates both media and political discourse (and even today's chic left-wing circles). Indeed, the subject has begun to seep into private life and individual awareness. The cult of the entrepreneur is advancing by leaps and bounds and is increasingly being taken for granted. Television is stuffed with 'personalities' radiating entrepreneurial energy: cooks, musicians, dancers, talented youngsters in the technology and/ or other fields. They are eagerly invited on to programmes so they can spread the word and 'blow their own trumpets' (the so-called 'personal branding' that exemplifies the entrepreneurship myth). There are also entrepreneurial businessmen yet over the last few years, what most stands out is the way a rag-bag of entrepreneurial notions has become part and parcel of subjects' personal lives. This has all happened in the wake of The Sub-Prime Crisis. The result is today's loose talk of 'entrepreneurial spirit' where it comes as something of a surprise to find the word spirit (with all its spiritual connotations) linked with entrepreneurial. Other associations, such as company and spirit are equally odd and - until very recently - were not in the same semantic field. These combinations (some might say oxymorons) are much like an invasive species that opportunistically take over a new habitat, replacing the native species.

While language and symbols are now saturated by the cult of the entrepreneur, it is in the social policy field that the cult is put into practice. Over the last few years, the pragmatic application of entrepreneurship has shaped the framework of job creation policies. One can say that the notion of entrepreneurship necessarily incorporates the idea of activation. This is because the entrepreneur is most commonly seen as someone who starts with a business idea, develops it, and (if successful) makes a great deal of money. This paper looks at the concept of 'employment activation' through this notion of the entrepreneur, of which our Neo-Liberal Age is so fond. The concept has many manifestations, including EU programmes such as Strategy Europe 2020. This programme has already been transposed into the national legislation of many EU Member States.

The idea of entrepreneurship has gained ground over the last two decades (especially over the last ten years). In the process, it has slowly displaced other ways of looking at the world to the point where other visions of reality have either vanished or been forced to fit in with a new, hegemonic breed of entrepreneurship. Nowadays, it is hard not to find the cult of the entrepreneur entrenched in the legislative framework. Twenty years or so ago, the cult of the entrepreneur spread to the EU but now the entrepreneur is the framework. Entrepreneurship is now the central pillar of the Europe 2020 strategy, whose avowed purpose is to foster a 'smart', integrating economy.

A detailed analysis of how international institutions convey, support, and implement given kinds of action programmes would require long, complex argumentation that is beyond the scope of this paper. However, our point of departure is the idea that: international institutions in the economic field (Bruno and Didier, 2013; Bourdieu, 1999; Hibou, 2012); business associations and lobbies (Dixon, 1998; Stauber and Rampton, 2004); educational institutions and training bodies (Slaughter and Larry, 1997; Alonso and Fernández, 2013, 2018; Fernández, 2017); professional corporations, consultancy firms and experts (Berrebi-Hoffmann and Grémion, 2009; Vrancken and Macquet, 2012) all pull the strings - whether openly or behind the scenes - to implement or spread entrepreneurial values and practices, which socialised subjects then incorporate through subjectivisation processes (Serrano, 2016). The EU is a public, transnational institution which, influenced by the neoLiberal context, fosters and makes choices, draws up co-ordinated strategies to disseminate, boost, and give effect to entrepreneurship and a certain notion 
of the entrepreneur. This model is a strategic factor for companies currently getting EU funding and the entrepreneurship paradigm has become an icon of deregulation in both symbolic and material terms for such firms. It facilitates the kind of labour market behaviour and training that favours the movement of ideas and capital.

We pay special attention to the period following the onset of the economic crisis in 2007, given the ideological battles over welfare unleashed by the slump. Liberal advocates of social cutbacks opposed alternative visions. Their views have prevailed and have led to the adoption of specific social and economic policy programmes. At the moment, the battle within the EU over such issues seems to have been won by those preaching austerity. In any event, the crisis is giving rise to reformulations. Owen Jones (2014) has called this 'Neo-Liberalism 2.0' - that is to say, a kind of refounding of Neo-Liberal Capitalism' after early doubts at the beginning of the crisis. In 2010, the phoenix rose from the ashes as it were, prompting a new drive to business profits and free markets (especially in financial markets). This use of a crisis to plough full steam ahead on the same course that took the economy onto the rocks was foreshadowed by none other than Milton Friedman (cited in 2014), who argued that only a crisis (whether real or imagined) produces real changes. In normal times, such changes would be politically impossible yet in a crisis, politicians can sell them as 'inevitable'. Our initial hypothesis is that the entrepreneurship agenda has become 'inevitable' in this sense and now holds the EU in its thrall.

One should note that the spread of entrepreneurship must be seen against a background of today's great social and labour upheavals. First, there is the steady corporativisation of salaried employment, with greater individualisation and accountability, especially in skilled jobs. Second, there is the crumbling of the bounds of salaried jobs stemming from a flood of new job types based on freelancing. Salaried work - especially for highly-skilled employees - is being re-thought and re-cast in an entrepreneurial mould. This redefinition gives rise to new practices and archetypes that deeply affect the world of work.

In the first section (I), we delve into the meaning of the notion of the entrepreneur and the role he plays in the steady corporativisation of work. The second section (II) frames this idea in the context of the Europe 2020 Strategy, where we analyse the main document covering entrepreneurship, namely: Entrepreneurship 2020 Action Plan. Reigniting the Entrepreneurial Spirit in Europe (EAP). In the third section (III), we look at several programmes and measures in the entrepreneurship field and stemming from EU-2020. The paper ends with a final section setting out our conclusions.

\section{APPROACH TO THE IDEA OF ENTREPRENEURSHIP: THEORETICAL ASPECTS}

As to the notions of entrepreneur and of entrepreneurial activation, one needs to go back to the beginning of Industrial Capitalism to trace the roles of businessmen in laying the foundations of classic economic policy and considering how these are reflected in today's world. Christian Laval (2015) analysed how Cantillon's Essai sur la nature du commerce en général (1755) already put over the businessman as a man everyone should model his life on. In Cantillion's view, the two biggest hallmarks of this mind set were: (1) heroism in embarking on a risky venture; (2) the element of calculation and rationality. Leaving aside the interest of following the spoor of the liberal businessman to describe the rise of the entrepreneur in today's Neo-Liberal setting, we should like to briefly mention works from the modern era (Feher, 2007; Foucault, 2007, Bröckling, 2015) - specifically in connection with the concept of human capital formulated by several Chicago School writers (especially Gary Becker). It was Becker who coined the term human capital back in the 1960s to convey the idea that everyone possesses capital and strives to maximise its returns. He and his disciples argued that we make choices in every aspect of our lives and that these choices are based on cost-benefit 
analyses. Our aim, the theory went, is that we seek to enhance aspects of our family and personal lives. All these behaviour patterns form part of the same utility function, whose sole purpose is to maximise one's personal 'income'. Even the most trivial decisions have a price and an individual is governed by this utility function when making his choice. Becker proposed this idea within the framework of American Neo-Liberalism, which stresses the role played by the individual in decision-making and economic behaviour. Everyone, Becker concluded, has to protect his own capital and take his own decisions. Thus there is no need for a State apparatus or regulations because society works all by itself. All that is needed is for individuals to strive, plan their behaviour and strategies in cost-benefit terms, and make their choices. Individuals, so the argument went, should behave like businessmen because this was the best way to maximise time and income. The idea was that life is 'capital' whose yield must be maximised. "The business of managing oneself" was what it boiled down to, commented Foucault (2007) in a text that has been widely echoed in recent sociological literature.

Following Michel Feher (2007), this reformulation of Becker's concept still belongs to Classic Liberalism, which saw human capital as the maximisation of future profits (which was also how the entrepreneurial model was understood throughout industrialisation). Nevertheless, from the mid 1980s onwards, a new twist was given to human capital that went far beyond the meaning given by Becker. The change was prompted by "the rise of Neo-Liberalism". Here, Feher considered that the business and employment worlds had been transformed by Financialisation, and with them the notion of human capital. Beyond 'the business of managing oneself' to maximise future 'incomes', human capital in the age of Financialisation invited the individual to see himself as manager of a portfolio of behaviours on which he took decisions. Such choices value the individual in question as a function of how attractive he is to companies. The difference this made was that individuals' decisions were less and less guided by obtaining future benefits given that the setting was one of growing uncertainty. It was not enough for financialised 'human capital' (that is to say, workers) to passively mould themselves to the demands of funded companies. Instead, workers were expected to foresee changes and prove their worth in the marketplace. Yet the market was plagued with uncertainties so that it was impossible to know which values were most profitable. Companies too had no idea of which values should be chosen. One therefore had to strive to make oneself more attractive to bidders, to accredit oneself - a bit like submitting oneself for judgment by a ratings agency - in order to gain some credibility. Under this new financing approach to human capital, one not only needs to be highly-skilled but also be willing to prepare for a yet-to-be-divined future.

Christian Laval described these behaviours as 'ultrasubjectivisation', that is to say "shouldering the notion of one's infinite improvement in an endless, exhausting quest beyond oneself [...]. In this revamping or progression of human capital, the subject is seen as a mere human replica of capital itself: liquid, volatile, and mutable" (Laval, 2015: 29). Job crafting is the penultimate step in this craze for personal development, treating the worker as 'an investor in himself' who has to invest in his future, know how to re-invent himself, reconfigure himself, and - as if all this were not enough - re-orient his work and draw up an 'investment plan'.

Acting like an entrepreneur is the best way of sending messages on the attractiveness of one's human capital in a period in which there are no 'beaten paths' to follow. Steve Banks, Professor at Stanford University and father of the Lean Start-up movement, highlights the fact that there is no end of theory on why established companies work but that this is useless when it comes to guiding start-ups. The reason is because start-ups begin with an idea - there is no cumulative knowledge on which to draw and thus the only guarantee of success (if one can call it that) is 'intuition and art', which must later be supplemented by management tools (El País, 2014). Thus the worker of tomorrow's world is cast 
as heroic visionary, artist and walking calculator. In her best-selling book The Shift: The Future of Work is Already Here (2012), the employment trends guru Lynda Gratton forecasts that tomorrow's employment world will be one of micro-entrepreneurs who have to train themselves while honing their networking and emotional intelligence skills.

This aesthetic of physical performance, dogged spirit, and business effort is supposed to make the 'human capital' discourse attractive. Yet one needs to look at the yawning gap between propaganda and facts, and between entrepreneurial rhetoric and business world practices. Although this is too ambitious an aim for this paper, it is worth looking at some of the contradictions between the ascetic ego [in the Freudian sense] demanded by a pretty theory and the grim reality of job insecurity in which cognitive work follows an iron entrepreneurial logic. The ideology of financialised human capital is a destabilising one over the short, medium, and long terms (Moruno, 2015). It creates uncertainty and inequality, making individuals responsible for managing themselves as if they were mere assets in a risk-capital portfolio, and it fosters the myth of equality of opportunities while hiding the true social conditions under which human capital and entrepreneurship operate. Moreover, it snares millions of young university students in what one might term 'the human capital trap' or the 'entrepreneurship trap'. The jaws of this trap are sprung by following the dictates of the human capital paradigm so that one behaves as if one were a company even though one knows that most firms die young. The risk capital fund run by Marc Andreessen (the creator of the very first web browser - Mosaic - and of Netscape) is considered by MIT Technology Review as one of the world's 100 most innovative people (MIT called him "a man who saw the future"). Andreessen analyses three thousand investment projects a year but only invests in fifteen. Of these, ten fail quickly, three or four stay afloat and - with a lot of luck - just one will become a big success (or in tech-speak, 'a unicorn'). Such successes are capable of yielding a one thousand-fold return for the risk capital fund but such 'unicorns' only crop up every ten years or so. There are 803 risk funds of this kind in The United States and in 2014 some $\$ 48,000$ million was spent searching for the mythical beast (Friend, 2015). It is a quest that thousands of post-graduate students pursue, spurred to take part as entrepreneurial human capital.

EUROPE 2020 AND THE ENTREPRENEURSHIP REVOLUTION: THE BROAD LINES AND DOCUMENTS OF ENTREPRENEURIAL POLICY IN THE EU-2020 STRATEGY

What form do EU-2020 programmes take as part of the entrepreneurship revolution we are describing here? The key document on entrepreneurship in the EU-2020 plan is titled Entrepreneurship 2020 Action Plan. Reigniting the Entrepreneurial Spirit in Europe (EAP). This is the document that lays down the broad lines for fostering entrepreneurship. Although it is a continuation of The Small Business Act, dreamt up for Small and Medium Enterprises (SMEs) in 2008, its monographic treatment of the role played by entrepreneurs is both innovative and symptomatic of the EU's orientations. The EAP echoes the kind of epic business discourses that have characterised the proposals for supporting entrepreneurs made by major business centres, business schools, and business associations over the last few years as if they offered the silver bullet to slay the undead crisis. The statements made by EU heads speak volumes. For example, Antonio Tajani, EU Commissioner for Industry and Entrepreneurship from 2010 to 2014, came up with the following gem: "To make it very clear: more entrepreneurs mean more jobs, more innovation and more competitiveness. Becoming an entrepreneur and making a vision come true takes a lot of personal risk and effort. Entrepreneurs are the heroes of our time. Entrepreneurship is also the most powerful driver of economic growth in economic history. (...) If we can unleash Europe's entrepreneurial potential, we can bring back growth to Europe"1 ${ }^{\prime \mathbf{1}}$. The message slavishly follows what one might term 'the

1 Statement consulted at http://europa.eu/rapid/pressrelease_IP-13-12_en.htm. 
heroic discourse of entrepreneurship' and might just as well have been dictated by business associations ${ }^{2}$.

The same EU-Big Business consensus can be found in the justification for the EAP, which is seen as key to recovering from the 2007 economic crisis and redressing the mass unemployment that came in its wake. The document begins by arguing that entrepreneurship is the answer to the crisis and even goes so far as to suggest that weakness in Europe's entrepreneurial culture was the reason for the slump. All this is based on the premise that entrepreneurship creates jobs and makes workers more employable. The EAP's first pillar proposes education and training in entrepreneurship to redress these shortcomings. To this end, the EAP draws up an action plan with alliances with international institutions such as the OECD, a pioneer in spreading the idea of entrepreneurship in schools. Here, the aim is to disseminate entrepreneurship through all levels of education and thus create an eco-system (a term littering the document and common in entrepreneurship jargon) that links the university world with the business world. This eco-system ranges from teacherpreneur (sic) in Primary Schools (Arruti, 2016) to university entrepreneurs. The EAP broaches the idea of funding these projects within the European Social Fund, differentiating them from the Lifelong Learning Programme (LLP), thereby boosting the scope and all-present nature of entrepreneurship education.

The EAP's second pillar is the creation of a setting that makes things easier for entrepreneurs. It comprises a set of initiatives that respond to the old, insistent demands made by business organisations: funding, tax breaks, new technologies, making it easier to set up and sell companies, plus measures giving failed entrepreneurs a second chance. With regard to fund-

2 See for example, the reports of Cercle d'Empresaris [business association] (2009): "The entrepreneurial spirit: A key element for dealing with Spain's economic crisis". The comments made by the Dean of IE Business School, Santiago Íñiguez de Onzoño were in the same vein: "Entrepreneurs will be the next generation's heroes" (El País, 4/1/2015). Last but not least, it is revealing to consult the international business networking platform, The Heroes Club, mentors of the entrepreneurial spirit. ing, as well activating the EU's own funds, the aim is to create a European micro-funding market and to simplify procedures so that small companies can raise money from the private sector (mini-bonds, forms of collective funding, and access to 'business angels'). With regard to new technologies, the aim is to broaden training, boost dissemination and awareness of the use of new technologies, and above all to develop cyber-entrepreneurship. Cutting down red tape and regulations are among EAP priorities: the 'one-stop shop', streamlining of procedures and other forms of deregulation have started a race to cut the costs and time involved in setting up a company. Last, given the high percentage of failed companies and to prevent the spirits of serial entrepreneurs from flagging, the EAP makes provisions to give failed businessmen a second chance to show what they can do.

The EAP's third pillar pursues two goals: the first is to spread the measures to groups that are excluded by or under-represented in the entrepreneurial world. This strand goes under the name of inclusive entrepreneurship, of which the OECD has experience and that now takes form in the EAP. This inclusive entrepreneurship' covers 'conventional' under-privileged groups: women, the elderly, immigrants, the unemployed, the young. Plans are drawn up for all of them to help them start a company, with business plans, entrepreneurship training and company management, how to get funding, documentation systems and the dissemination of best practices. The second goal of this third EAP pillar is to boost and highlight the role played by entrepreneurs given that the EAP notes (somewhat surprisingly) that: entrepreneurs are discredited and the public knows little about them; there is a lack of entrepreneurship models; entrepreneurship is seen as an undesirable profession. A 'positive communication strategy' is planned, with an 'EU Entrepreneurship Day', the appointing of famous entrepreneurs from each Member State as "National Entrepreneurship Ambassadors", and in general ramping up promotion activities and boosting entrepreneurs' image in a business-friendly fashion. The EAP's drafters end the document with an apology for the entrepreneurship world: "A cor- 
responding broader discussion in public, especially in the media, is thus essential for an entrepreneurial revolution. Public and private institutions should be encouraged to emphasise the social and economic importance of entrepreneurs not only as a legitimate career path but also as a matter of utmost national, European and international interest".

Given that the entrepreneur bestrides today's media like a Colossus, it is surprising the EAP's drafters felt the need to praise entrepreneurs to the skies throughout the text and to highlight - of all things - our ignorance of the benefits they bestow on society. Since the beginning of the crisis in 2007, business circles in OECD countries have put the propaganda machine into full gear to laud entrepreneurs and companies. This gave rise to a new episode of what Tomas Frank $(2000,2013)$ has termed 'market populism'. This strategy consists of glorification of entrepreneurs, companies, and the Capitalist system in general and key business institutions in particular. The cheerleaders here are business circles and the most 'corporate-friendly' political parties. This strategy has been used before and - according to Frank - is intensified during economic crises, when companies' reputations and responsibility for the mess come into question. The outbreak of market populism spawned by the 2007 crisis took the form of bombarding the media with stuff on entrepreneurship and weaving a tale in which entrepreneurs were presented as the economy's salvation, with the finger of blame for the crisis being pointed elsewhere. The media blitz was also intended to strengthen the business lobby and demands that State regulations and funds be harnessed to serve entrepreneurs' interests. Entrepreneurs were presented as paragons of progress and innovation, given media haloes, and passed off as lovers of freedom (especially market freedom). One only need look at the spate of news items and initiatives (fairs, company accelerators, magazines, TV programmes, scholarships, internships, competitions, prizes, funding calls, and so on) to see that the 'entrepreneurship revolution' is already well under way.

The EU is wide open to these influences through a host of pro-entrepreneurship programmes in its EU-2020 strategy. It is not that the EU lacked business-friendly leanings before the 2007 crisis but from then on, the entrepreneurship groupies have become better orchestrated and organised, as one can deduce from the way the EAP is structured. Lack of space in this paper precludes us from delving into the details of all the related EU programmes and the seeding of entrepreneurship in European countries. Nevertheless, in the following section we describe several cases in which Member States have recently enacted national legislation on entrepreneurship to transpose the EU-2020 strategy.

\section{ENTREPRENEURSHIP'S RESONANCE IN VARIOUS EU MEMBER STATES}

The entrepreneurial spirit of the EU programmes described in the foregoing section is not only reflected in the European Union's own programmes but also in the legislation of each Member State. Over the last few years, many pro-entrepreneurship Acts have been passed. This means one can start assessing their impact on employment. We shall briefly review the cases of France, Portugal, and Spain. The aim here is neither to compare the data nor to exhaustively analyse each case. Instead, we merely show similarities among the entrepreneurship measures taken in various European countries.

In the French case, 'crisis legislation' was swiftly enacted to foster entrepreneurship. The Statut d'autoentrerpreneur [Statute of Self-Employed Entrepreneurs] was passed in 2009 and its scope has expanded greatly since then. The preamble to the Act lauds the ability of the legislation to help entrepreneurs by creating quality jobs, innovation, and autonomy. Nevertheless, with hindsight, one can appreciate its huge potential for spawning job insecurity. The real negative impacts of the Act have been described by Pereira (2010), Stevens (2012) and Abdelnour (2017). They include: (1) very low incomes for young self-employed entrepreneurs; (2) companies taking advantage of the system to outsource work (laying off workers and replacing them with self-employed 'entrepreneurs'); (3) making the 'entrepreneurs' pay their own Social Security contri- 
butions, thereby saving outsourcing companies even more money; (4) effectively scrapping redundancy payments and severance procedures. In both social and employment terms, self-employed entrepreneurs pay dearly for being their own bosses. They have no right to unemployment benefits, they operate in a pseudocorporate limbo in which Trade Unions cannot help them, and they feel (and are) isolated.

Thanks to the reverse alchemy of the Statut d'autoentrepreneur (whereby salaried workers become dirtcheap sub-contractors), roughly a million potential salaried workers have been turned into 'self-employed entrepreneurs'. Experts interpret this growth in selfemployment as masking functional unemployment by spawning insecure jobs. The self-employed entrepreneurs receive income but they lose rights, security, and social protection. Here one should add an element of self-exploitation. This is the result of a downward spiral in rates, with the victims desperately offering cut-throat prices to attract the biggest companies.

"Portugal Discovers its Spirit of Entrepreneurial Adventure" was the breezy headline in Forbes Magazine in an August 2015 report. The famed publication described the astonishing speed with which an entrepreneurship culture had taken root in Portugal. There was a spate of private and public initiatives that gave rise to a host of projects, such as Lisbon Challenge, which was rated as one of the five most active 'start-up accelerators' in Europe (Coleman, 2015). Yet this yen for entrepreneurship in Portugal is nothing new. Back in the early 1980s, the Instituto do Emprego e Formação Profissional (IEFP) - the national training service - had a long history of programmes for boosting jobs through entrepreneurship. Since then, these programmes have placed large numbers of Portuguese workers in the trabalho independente [self-employed] category according to the Instituto Nacional de Estatística (INE) [national statistics bureau]. The figures show that self-employed workers make up almost $22 \%$ of Portugal's active population. These independent workers are popularly known as recibos verdes [green receipts] in Portugal because of the colour of the books of invoices they have to use to account for their business activity. The green receipts have been considered by various authors (Soeiro, 2014; Matos, Domingos and Kumar, 2012) as the main mechanism driving job insecurity in Portugal. One of the reasons for this is the growing practice known as 'sham green receipts', which basically consists of replacing salaried workers by self-employed workers who invoice only one company (their real employer). This practice has led to widespread protest, led by movements such as Geração à Rasca [Struggling Generation], and Precários Inflexíveis i Fartas/os d'Estes Recibos Verdes [Sham SelfEmployed Workers Sick of Green Receipts].

In this context, the Portuguese Government passed its Programa Estratégico para o Empreendedorismo e Inovação (PEEI) [Strategic Programme for Entrepreneurship and Innovation] in December 2011. The PEEI ties in with the EU-2020 strategy and its four main goals are: (1) the creation of a "more entrepreneurial society"; (2) boosting the number of innovative companies; (3) positioning Portugal among international entrepreneurship and innovation networks; (4) boosting foreign investment in Portugal. Through actions such as Passaporte para o Empreendedorismo [Entrepreneurship Passport], the Rede Nacional de Mentores [National Mentoring Network] and Programa de Ignição ['Ignition' Programme], the PEEI seeks to foster entrepreneurship and broaden the 'entrepreneurial skills' of the Portuguese. One should note here that the top co-ordinating body for this plan is headed by the Prime Minister and a Committee whose members are leading businessmen with links to Risk Capital Funds, Start-Up Accelerators, and other initiatives tied in with the entrepreneurship eco-system. Through the PEEI, as well as by meeting the demands of EU-2020, one can hazard a guess that the Portuguese Government is trying to deepen the penetration of the new entrepreneurship activation doctrine. Despite the big protests held by the recibos verdes (leading to a publicly-sponsored Bill, debated in the Portuguese Parliament in 2016) (Soeiro 2014; Estanque, Costa and Soeiro, 2013), the Government has forged ahead with its approach. It has done so without taking into account entrepreneurship's general failure to dent the nation's appalling joblessness (which is largely the fruit of the Government's stubborn, misguided policies). 
The Spanish case is similar to the French one. The Estratègia d'Emprenedoria i Ocupació Juvenil [Strategy for Entrepreneurship and Youth Employment] 2013/2016 (EEOJ) was passed in 2013, together with the Llei de suport als emprenedors i la seua internacionalització [Entrepreneurial Support and Internationalisation Act] (LE). Both texts were drafted against the background of today's economic crisis and were driven by the symbolic rise of the entrepreneur. In their preambles, both the EEOJ and LE refer to Spain's alarming unemployment. What is surprising is the naturalness with which they suggest entrepreneurship as the solution and 'creating one's own job' as the only way out of mass unemployment. Both texts share the same (preconceived) idea that fostering entrepreneurship will boost job creation. Nevertheless, this apparently automatic link is not borne out by the analysis accompanying the two legal texts. In fact, quite the contrary given that both documents note how unemployment is hitting small companies and the self-employed harder than most (with difficulties in raising loans, companies going bust, little ability to create jobs, lay-offs, and red tape, among other problems).

The main steps taken by the EEOJ to promote entrepreneurs are: (1) the so-called 'flat rate contributions for the self-employed', based on first-year discounts for young people registering as self-employed (Spain's Règim Especial de Treballadors Autònoms); (2) establishing eligibility for unemployment benefit from the moment one begins to work for oneself, and widening the options for capitalising unemployment benefit when this is used for shares in a company; (3) the so-called Emprén amb Xarxa approach [Networked Entrepreneurship], which allows an entrepreneur whose business has failed, to once again receive unemployment benefit. There are also measures covering advice, and lastly, there is a Contracte Generacions [Generational Solidarity Contract] which gives a discount to entrepreneurs who hire someone who is both jobless and over 45 .

These measures have already prompted criticism - for example of the 'flat rate', which clearly falls far short of what is needed to begin a business and give it a decent chance of survival. This measure suggests that anyone can be an entrepreneur but fails to provide the means needed to make it so. With regard to the other measures ('squaring getting unemployment benefit with a business activity' and 'Networked Entrepreneurship'), both initiatives are a sign of desperation, given that they seek to make those on the dole believe that they must create their own jobs. Indeed, the first initiative suggests that someone without a job can both receive unemployment benefit and entrepreneurship subsidies. The second initiative allows someone to go back on the dole if he fails as an entrepreneur. These provisions show that the EEOJ has little faith in the chances of entrepreneurship succeeding and foreshadows a path strewn with failures and frustration, in which the subject fails as an employee and is fired, fails yet again as an entrepreneur, and then fails a third time when he goes back on the dole.

Given the foregoing arguments, the entrepreneurship picture painted by the EEOJ is far darker than the creative, innovative image of entrepreneurs trotted out for public consumption. The EEOJ is a canvas varnished with entrepreneurial jargon but beneath is a tableau of people who resort to entrepreneurship out of desperation and who are destined to cover lowskilled, poorly-paid activities. Instead of giving us the archetypal creative entrepreneur, the EEOJ palms us off with lumpen entrepreneurs doomed to provide low added-value products and services. An army of sham self-employed workers have been spawned by job insecurity over the last two decades. The new forms of self-employed entrepreneurship are the latest turn of the screw, blithely rebadging self-employed workers as 'businessmen'.

\section{CONCLUSIONS}

We can highlight three provisional conclusions. The first is that the impact of the entrepreneur cult is widening ever faster. The term 'entrepreneur' is used to mean all things to all men: as an economic actor in the corporate world; as a way of describing work; as part of an 'activating' employment policy; as an aptitude for acquiring knowledge and know-how; 
(even) as an attitude to life. The entrepreneur is not merely presented as an economic actor but also as a way of life that will foster a business society in which legal or political issues - the very source of our rights and duties - become matters of 'life management' as if the individual were a company. The whole miasma surrounding entrepreneurs is presented in enthralling language, as if Homo Entreprenaurus [Enterprise Man] had a monopoly on passion, vision, and spirit. The idea that everyone has to create his or her job had become commonplace and promises to share the aforementioned virtues with whoever decides to take the entrepreneurial path. This is the language beloved by business publications and which is shared by the EU-2020 documents we analysed earlier.

The second conclusion is that the EU disseminates and subscribes to this 'entrepreneurial spirit', embodying it in its programmes. In this paper, we have seen the details of the Entrepreneurship 2020 Action Plan (EAP) and the measures it contains. This strategy consolidates an orderly market peopled by authoritative business actors 'playing by the rules' and who project a policy framework favouring companies and the free market. Public institutions are thus thrown open to competition, which then becomes the bedrock of the new political order. The most important aspect of this process, argue Dardot and Laval (2016), is the way the EU makes these market rules. Instead of being democratically drawn up through parliamentary debate, they are cobbled together by technocrats working hand-in-glove with corporate interests. The result is a supranational strategy that is imposed through EU rules. This homogeneous, supra-national approach saves Member States' governments the dirty job of having to overcome resistance to these policies, thus ensuring market forces win the day. This process hinders the building of European unity based on political co-operation and social solidarity and instead establishes a technocratic government based on business logic and served by a host of bureaucrats, judges, and penalties. Such control over decision-making is a theme of great interest today. Didier Georgakakis (2012) in his sociology of EU staff, Sylvain Laurens (2015), with her 'micro-communities' among EU bureaucrats, business lobbying, and the works by Dardot and Laval (2016) cited earlier all offer valuable clues to the 'quick fixes' dreamt up by high-level EU officials, the technical departments of central banks, and economic and financial bodies in EU Member States when it comes to making the rules. These groups share the same training based on US-influenced transnational members of the management class who have the know-how/power to impose rules, establish statistical and technical criteria and apply technocratic control to economic life. The "gentle monster of Brussels" of which Enzensberger (2012) spoke of is currently pulling the strings behind the stage-set of creative entrepreneurship.

The third conclusion is that the promises made by the entrepreneurship regime do little to: (1) tackle job insecurity and powerlessness (both ills mentioned in the EU documents analysed earlier); (2) foster a competitive, society based on knowledge, talent, and social cohesion. Instead, they spawn armies of freelancers, the self-employed and young businessmen. For these groups, the 'entrepreneurial spirit' means exchanging job insecurity as an employee for job insecurity as a self-employed entrepreneur by force of circumstances. Entrepreneurial excellence and success only occur under certain conditions that always favour the best-positioned members of society (who move in de-territorialised, trans-spatial settings and who can take risks when the odds are right). By contrast, the vast majority of mortals must work in local settings and on specific projects upon which their fate depends. This involves both greater flexibility and risks but without greater expectations. French autoentrepreneurs, Portuguese recibos verdes, and Spain's autònoms are the flip side of the start-up unicorn. In the entrepreneurship universe, only a few stars shine brightly, concealing dark worlds and their lumpen entrepreneur denizens 


\section{BIBLIOGRAPHIC REFERENCES}

Abdelnour, S. (2017). Moi, petite entreprise. Les auto-entrepreneurs, de l'utopie à la réalité. París: Presses Universitaires de France.

Alonso, L. E. and Fernández Rodríguez, C. (2013). Los discursos del management. Una perspectiva crítica. Lan Harremanak. Revista de relaciones laborales, 28, 42-69.

Alonso, L. E. and Fernández Rodríguez, C. (2018). Poder y sacrifico. Los nuevos discursos de la empresa. Madrid: Siglo XXI.

Arruti, A. (2016). El desarrollo del perfil del teacherpreneur o profesor-emprendedor en el currículo del grado de Educación Primaria: ¿un concepto de moda o una realidad? Contextos educativos: Revista de educación, 19, 177-194.

Berrebi-Hoffmann, I. and Grémion, P. (2009). Élites intellectuelles et reforme de l'État. Esquisse en trois temps d'un déplacement d'expertise. Cahiers internationaux de sociologie, 26(1), 39-59.

Bourdieu, P. (1999). Contrafuegos. Reflexiones para servir a la resistencia contra la invasión neoliberal. Barcelona: Anagrama.

Bröckling, U. (2015). El «self emprendedor». Sociología de una forma de subjetivación. Santiago de Chile: Universidad Alberto Hurtado.

Bruno, I. and Didier, E. (2013). Benchmarking. L'État sous pression statistique. Paris: La Découverte.

Coleman, A. (2015). Portugal Discovers Its Spirit Of Entrepreneurial Adventure. Forbes. Consulted on the 28th of March 2017 at https:// www.forbes.com/sites/alisoncoleman/2015/08/23/portugal-discovers-its-spirit-of-entrepreneurialadventure

Cordero, D. (2014). Un plan de negocio es inútil en una startup. El País. Obtained from http://economia.elpais.com/ economia/2014/03/21/actualidad/1395424206_595886.html

Dardot, P. and Laval, Ch. (2016). Ce cauchemar qui n'en finit pas. Paris: La Découverte.

Dixon, Keith (1998). Les évangélistes du marché. Paris: Raisons d'Agir Éditions.

Enzensberger, H. M. (2012). El gentil monstruo de Bruselas o Europa bajo tutela. Barcelona: Anagrama.

Estanque, E., Costa, H. A. and Soeiro, J. (2013). The New Global Cycle of Protest and the Portuguese Case. Journal of Social Science Education, 12(1), 31-40.

Feher, Michel (2007). S'apprécier, ou les aspirations du capital humain. Raisons politiques, 28(4), 11-31.

Fernández, C. and Medina-Vicent, M. (2017). Los nuevos discursos del management: difusión, impactos y resistencias. Recerca: Revista de Pensament i Anàlisi, 20, 7-14.

Frank, Th. (2000). One Market Under God. New York: Anchor Books.

Frank, Th. (2013). Pobres magnates. Madrid: Sexto Piso.

Friend, T. (2015, 18th May). Tomorrow's Advance Man. The New Yorker. Obtained from http://www.newyorker.com/ magazine/2015/05/18/tomorrows-advance-man

Foucault, Michel (2007). Nacimiento de la biopolítica: Curso del Collège de France (1978-1979). Buenos Aires: Fondo de Cultura Económica.

Georgakakis, D. (dir.) (2012). Le champ de l'Eurocratie, une sociologie politique du personnel de l'UE. Paris: Economica.

Gratton, L. (2012). Prepárate: el futuro del trabajo ya esta aquí. Madrid: Galaxia Gutemberg.

Hibou, B. (2012). La bureaucratisation du monde à l'ère néolibérale. Paris: La Découverte.

Jones, O. (2014). La política de la envidia. La Maleta de Portbou, 7.

Laval, Ch. (2015). La precarietà come «arte di vivere» nell'epoca neoliberalista, In S. Contarini and L. Marsi (eds.), Precariato. Forme e critica della condizione precaria. Verona: Ombre corte.

Laurens, S. (2015). Les courtiers du capitalisme. Milieux d'affaires et bureaucrates à Bruxelles. Marsella: Agone.

Matos, J. N., Domingos, N. y Kumar, R. (2012). Precários em Portugal: entre a fâbrica e o call center. Lisboa: Le Monde Diplomatique.

Moruno, J. (2015). La fábrica del emprendedor. Madrid: Akal.

Pereira, I. (2010). Du salariat à el auto-entreprenariat: vers plus de liberté ou vers plus de exploitation? Sud Cultures Solidaires. Consulted on the 27th of March 2014 at http://sud-culture.org/expressions/spip.php?article1006

Serrano, A. (2016). ). Colonización política de los imaginarios del trabajo: la invención paradójica del emprendedor. In E. Gil Calvo (ed.), Sociólogos contra el economicismo. Madrid: Libros de la Catarata. 
Slaughter, S. and Larry L. (1997). Academic Capitalism. Politics, Policies and the Entrepreneurial University. Baltimore: The Johns Hopkins University Press.

Soeiro, José (2014). De Geração à Rasca a Que Se Lixe a Troika: Portugal en el nuevo ciclo de protestas internacionales. Sociologia, 28, 55-79.

Stauber, J. and Rampton, S. (2004). L'industrie du mensonge. Relations publiques, lobbying et démocratie. Marsella: Agone. Stevens, H. (2012). Le régime de l'auto-entrepreneur: une alternative désirable au salariat? Savoir/Agir, 21, 21-28.

Vrancken, D. and Macquet, C. (2012). Focus. Du travail sur soi au gouvernement de soi. Informations sociales, 169, 76-79.

\section{BIOGRAPHICAL NOTE}

\section{Antonio Santos Ortega}

PhD in Sociology and Professor of the Department of Sociology and Social Anthropology at Universitat de València (UV). He has done research on youth, unemployment, under-employment and job insecurity. Santos has published in Sociología del Trabajo (https://recyt.fecyt.es/index.php/sociologiatrabajo), Sociologia del Lavoro, and International Review of Sociology. He is a member of the Advisory Council of Quaderns de relacions laborals and of the Social Sciences journal Arxius.

\section{David Muñoz Rodríguez}

PhD in Sociology and Associate Professor at the Department of Sociology and Social Anthropology at Universitat de València (UV). His research lines cover processes fostering job insecurity, youth, social and political movements, and public policies. Muñoz has published papers on these subjects in journals such as REIS: Recerca i sociología del trabajo, among others. 